\title{
Japan's Nightingale Geisha Singers: Listening to Women Through Audio Media
}

\author{
Gretchen Jude \\ Research Fellow, Yokohama National University \\ 79-1 Tokiwadai, Hodagaya Ward, Yokohama, Kanagawa Prefecture 240-8501, Japan \\ e-mail: gretchenjude@gmail.com \\ *Corresponding author: gretchenjude@gmail.com
}

Published: 27 November 2020

Cite this article (APA): Jude, G. (2020). Japan's nightingale geisha singers: Listening to women through audio media. Malaysian Journal of Music, 9, 101-114. https://doi.org/10.37134/mjm.vol9.8.2020

\begin{abstract}
This paper examines the emergence and disappearance of Japan's geisha kashu recording stars over the course of the $20^{\text {th }}$ century, delving into their extensive body of audio recordings, which includes songs by some of Japan's most important early popular composers. Clarifying the distinction between geisha and the geisha recording stars, this paper traces the relationship between "traditional" Japanese musical forms (specifically, the complex of short shamisen songs long associated with geisha) and the popular genres that also comprised the geisha stars' repertoire. While historical audio media provide a valuable resource for scholars and fans alike, unconscious habits and unexamined discourses of listening may lead to the replication of orientalist and sexist stereotypes - and ultimately a superficial experience of the music. As a corrective to such tendencies in audience reception, this paper gives an overview of the key cultural and historical contexts of the geisha recording stars, including their contributions to the careers of several of well-respected composers. Attending to the sometimes difficult circumstances faced by geisha recording stars (and their geisha sisters) may rectify the image of these critically neglected women artists, ultimately providing a necessary counterpoint to the predominance of male musicians and male-centred musical genres in the Japanese canon.
\end{abstract}

Keywords: alternative modernity, phonograph, popular music, traditional Japanese music, women in music

\section{Who Were the Nightingale Geisha Singers?}

The striking visual appearance of geisha as they play their role as living symbols of traditional Japan makes their distinctive clothing and makeup a familiar sight in advertisements and tourist photos. Ironically, however, the music of these artists remains stubbornly outside the purview of contemporary imagination. As Downer (2014) points out, the geisha in her role as virtuosic performer typically remains obscure-even to most Japanese people, who are decidedly "not interested in [geisha]" (p. 224). According to Foreman (2008), despite these artists' hard-earned expertise and their dedicated efforts to maintain centuries-long performance traditions, geisha remain less likely to receive institutional financial support than performers of more famous genres such as kabuki and noh - which remain nearly exclusively male realms, particularly at the professional level ( $p$. 100). For centuries prior to modernisation in 1868, geisha were one of the few groups of women allowed to dedicate their lives to musical practice. Yet there remains a paucity of scholarship on the music of geisha, in particular the myriad short song genres that they were central in creating and disseminating. Today, even the average Japanese person has little 
knowledge of what geisha sound like, in part because contemporary artists emphasise live rather than mediated performance or studio recording.

Luckily, audio and audio visual media, which spread through Japan starting in the late $19^{\text {th }}$ century, provide ample documentation of several dozen long-neglected uguisu geisha kashu [lit. nightingale-geisha-recording-star], whose careers spanned the period from the 1920s until the 1990s and included a range of traditional and popular music genres. Recordings on media ranging from 78 discs (called "SP records" in Japan) and LPs to cassettes, CDs and DVDS are still distributed and rereleased by major labels like Victor and Columbia (Fukkoku, 2005; Uguisu, 2018). Older recordings that have gone out of copyright can also be found informally catalogued and distributed online by fans, as well as in private amateur collections such as the Kanazawa Phonograph Museum¹.

Recordings are a valuable resource for scholars and fans alike, allowing repeated listening to music that may be otherwise completely inaccessible. For example, through close listening to Japanese popular singing styles over the $20^{\text {th }}$ century, de Ferranti (2002) postulates an underlying continuity of vocal habitus, specifically the vocal quality called jigoe [lit. "ground-voice", often translated as "chest voice"], which he describes as "a thin, somewhat rasping yet strong tone produced by forcing a narrow, dense air stream through constricted vocal cords" (p. 202). According to de Ferranti, this vocal quality can be found in recordings by female singers throughout the $20^{\text {th }}$ century, from pre-war geisha to enka singers of the 1970s and J-pop stars of 1990s. While I agree that de Ferranti's observation holds up when comparing Japan's pop divas with non-Japanese singers (as well Japanese singers who have non-Japanese vocal training), I also find that the extensive listening practices enabled by audio media may reveal subtle but crucial distinctions in singing style between various communities of musical practice within Japan.

I examined two recordings of the same Edo-Period song, "Ume Wa Saita Ka" [Has the Plum Blossomed], one sung by a geisha recording artist from the 1930s and one by an enka singer several decades later. The contrast in vocal quality and style is subtle but clear.

[Fujimoto Fumikichi's] jigoe timbre sounds slightly pinched through the limited frequency range of the primitive microphone, but her intricate yet effortless deployment of kobushi ornamentation has a filigreed quality that flutters into my listening awareness. The bright ringing quality of her vocal resonance pings through the decades, even as her lips sound barely parted...[In contrast,] Misora [Hibari] engages a similar jigoe timbre, yet her yuri ornamentations are much wider in pitch while more centrally focused around a single note in the melody. Perhaps more prominently, Misora emphasises the places in the melody where her voice passes over her register break, and digs into the lower part of her range with an near-grunting quality. The final syllable of the vocable sequence at the end of each verse is particularly resonant. (Jude, 2018, pp. 39-40)

Such close listening practice helps elucidate the moniker "uguisu geisha kashu" since the nightingale, for all its symbolic valences, also aptly evokes the singers' plaintive, agile warbling vocal style, marked by quavering, skilfully controlled kobushi [lit. small-melody; translated as "ornamentation" (Yano, 2002) or "tremolo" (Wright, 2016)] as opposed to the yuri [lit. shaking; i.e., vibrato (Yano, 2002)] found in enka, an analogue to American country music that is still widely heard today (Hughes, 2008, p. 42). In addition, early geisha recording stars were often high sopranos, although alto Akasaka Koume was a notable exception. That so many recordings of these singers are still available provides valuable, first-hand access to the sound itself.

However, even as media technology provides experience of sonic actualities, it also creates potential listening situations in which a lack of context and cultural knowledge unwittingly cultivates orientalist modes of explanation, as theorised by Kheshti (2015). Listening as a consumerist activity tends to essentialise and exoticise the artists, obscuring the rich significance of their music rather than promoting deeper understanding of individual 
musicians within complex circumstances. The further removed a recording is from a listener's own natal sociolinguistic and cultural context, the more possibility there is that the gap in context will render a performance illegible - meaning an uncritical listener will be prone to fill in that context in potentially inaccurate (and even offensive) ways. Listening to geisha born over one hundred years ago requires dedicated listeners to examine not only their lack of contextual knowledge but also their own potential to exoticise and objectify these singers who look and sound thrillingly unfamiliar.

In this paper, I spotlight the geisha recording artists of the early and mid- $20^{\text {th }}$ century, most of whom I initially discovered via their recordings - and some of whom remain completely obscure except for those recordings. In order to avoid the orientalist and objectifying modes of listening that Kheshti cautions against, I provide the historical context of the geisha singers' work, including information about the famous composers whose songs the geisha recording artists popularised, as well as their primary genres, which spanned and often blended the most popular music of the early $20^{\text {th }}$ century with the Edo song forms now codified as traditional.

\section{Out of the Geisha Houses and Into the Recording Industry}

Although the geisha recording stars, with few exceptions, all started their singing careers as geisha, the inextricable ties between an individual geisha and her local community of fellow entertainers meant that the uguisu geisha kashu were no longer geisha per se, since a media star's new public role meant that she left the geisha neighbourhood (or hanamachi). This echoed the way that geisha have long left behind their birth names, along with their natal homes, to become professional performers in their hanamachi, and give up these professional names upon retirement for new undertakings such as marriage.

Furthermore, while some geisha kashu retained the name of their point of artistic origin, the biggest geisha stars floated free even of those place markers. Shinbashi Kiyozō and Akasaka Koume, who came to Tokyo from the distant island of Kyushu, took the names of their hanamachi of Tokyo upon arrival in the capital (Nakayama, 1958; Osada, 1998). In contrast, Kouta Katsutarō, who left her hometown of Niigata to work in the famed Tokyo geisha neighbourhood of Yoshichō, chose her favoured genre, kouta, as her surname once she found success as a recording artist (Kurata, 1979). Similarly, in 1933, success as a media performer allowed Asakusa Ichimaru to leave behind her hanamachi-along with its name. In 1960, Ichimaru, honoured with an artistic lineage name, became Edo Kouta Ichimaru, the name which appears on her gravestone in the sleepy hot-spring town of Asama Onsen where she first became a geisha. Even after departure from their communities, the names of geisha kashu linked them to hanamachi regimens of artistic training and distinctive forms of dress, comportment and speech-even as their names often shifted to indicate their new public personae, sometimes in complicated ways that reflect their shifting life circumstances. ${ }^{2}$

\section{The Three Strings of the Floating World}

The shamisen, a fretless, three-stringed plucked chordophone with a skin-covered resonating body, which arrived in Kansai from Okinawa in the late $16^{\text {th }}$ century, became the emblematic instrument of the Edo Period, and remains the primary instrument of geisha. During the same time period, as centres of power and culture shifted from Kyoto to Edo, so-called pleasure quarters were established in cities and towns across the archipelago, which became increasingly influential sites of artistic creation and inspiration. The shamisen was adapted to and adopted in myriad music that remain widespread today, such as kabuki, bunraku puppet theatre and regional folk traditions, as well as the genres mastered by geisha ensconced in the 
pleasure quarters. According to Groemer (2008), hundreds of short shamisen song genres emerged, gaining prominence concomitant with the rise of the vibrant urban culture of Edo.

The geisha played an active part of this urban culture, even though their performance venues were legally restricted to private parties until after the Meiji Restoration in 1868. As Foreman (2008) details in her ethnography of contemporary Kyoto geisha, their expertise has long included both long narrative genres such as nagauta (most commonly heard in kabuki), tokiwazu and kiyomoto, along with simpler short-song forms like hauta, utazawa and kouta (sometimes called edo kouta). All of these shamisen genres, both short and long, remain intimately linked to the aesthetic of the floating world.

The floating world, or ukiyo, is most famously portrayed in ukiyoe [lit. floating-worldpicture] woodblock prints of kabuki actors and urban scenes - and of course, Edo's glamorous courtesans and geisha. The metaphor of the floating world, with its associations of ephemeral enjoyment and freedom from mundane responsibility, originated in the classical courtly traditions of the Heian Period (794-1185), but fully came to fruition in the Edo Period. Performers, both on public kabuki stages and in the circumscribed feminine realm, were central to this aesthetic.

Also central to this refined sphere was the $y \bar{u} k a k u$ [lit. play-enclosure]. Yükaku is typically translated as "pleasure quarter" but given the uneven distribution of "pleasure", it may be more accurate to gloss the term as "licensed district" - the walled-in areas, such as Edo's emblematic Yoshiwara district, where prostitution could be practiced legally, and where other entertainments, including music and dance by geisha (who were legally forbidden from prostitution) were also offered to (male) customers.

Given the historical as well as cultural distance of this context from contemporary audiences, it is challenging for modern and particularly non-Japanese people to fully comprehend the affective power of the floating world aesthetic as it was rooted in the cultural context of the time. Dalby (1995) suggests that it is "more appropriate to think of the yukkaku as a theme park than as a Western-style red-light district" as such places "embodied and represented an idealised notion of romance" (pp. 54-55).

In the $y \bar{u} k a k u$, men of the highest class (samurai) and lowest class (merchant) could expect equal treatment as customers; nonetheless, due to the expense involved, escape into the floating world was nothing but a fantasy for most men. Whereas the $y \bar{u} k a k u$ designated a space where wealthy men of taste enacted aesthetic and bodily pleasures, the term kary $\bar{u} k a i$ [lit. "flower-and-willow-world"] — although sometimes used interchangeably with yükakuis more abstract, and indicates more explicitly women's creative roles in the floating world aesthetic. In the symbolism of the term, the flower and the willow indicate courtesans and geisha respectively. This emphasises the centrality of women as professionals employed within the context of the floating world, as well as indicating how deeply intertwined geisha and $y \bar{u}$ jo [lit. play-woman; i.e., courtesan] were in this aesthetic. While the $y \bar{u} k a k u$ as physical enclosure no longer exists, the term karyükai is still used in reference to the purview of contemporary geisha. Even though today the karyükai does not include the overt sexual commerce provided by the "flower" (or courtesans), the arts of the geisha nonetheless contain lingering echoes, including song lyrics that are not fully comprehensible without knowledge of women's roles in the floating world (Jude, 2018).

\section{Modernising Geisha}

The authorship of the short songs performed and passed down by geisha in the karyükai often went unattributed. Yet the songs were immensely popular, especially in rapidly expanding Edo. By the end of the 1800s, hauta (such as "Ume Wa Saita Ka") became distinguished stylistically from newly-emerging short-song forms: first utazawa, which Wright (2016) 
describes as "slower and more elegant" than hauta, then edo kouta, short songs that were "quicker and more expressive" than utazawa (p. 122). Wright observes that the three genres are commonly described in familial terms, with hauta as the mother of two sisters, utazawa and kouta (Groemer, 2008). As Japan emerged as a modern nation-state and Edo was renamed Tokyo, these shamisen genres vied for position of most fashionable songs of the late $19^{\text {th }}$ century. Edo kouta emerged as a distinct genre in the Meiji Period (Foreman, 2008, p. 26 ), emerging as most popular of the short shamisen songs by the start of the $20^{\text {th }}$ century (Groemer, 2008, p. 275).

At the same time, these small-song forms developed in conjunction with the rise of iemoto lineage masters teaching the genres (reflecting Japan's traditional ryüha system, in which artistic lineages are inherited). Unlike most ryüha, which pass down through male descendants, many of the early iemoto of short song genres who started lineages - such as kouta master Kasuga Toyo in 1930 (cf. Wright, 2016) were female (Foreman, 2008, p. 27). This likely stemmed from the fact that for centuries the musicians who most often played these genres were geisha.

In short, changes in political policies and social mores during the late $19^{\text {th }}$ and early $20^{\text {th }}$ century provided new opportunities for female musicians, including geisha, who not only continued their traditional practices but also expanded into the public arena, epitomised by Kyoto's annual proscenium-staged performances such as Miyako Odori and Kamogawa Odori (Okada, 2010).

Despite their early influence on musical culture, geisha as such have never become full-fledged stars in the modern sense; they do not record albums of newly composed music or perform on tour as solo artists or ensembles. However, for a brief historical period, a few geisha took their training in song, dance, shamisen and hayashi percussion ensemble instruments (taiko, otsutzumi and kotsutzumi) - along with their sumptuous kimono collections (Till et al., 2001) — and left their artistic communities to become popular solo recording artists. These uguisu geisha kashu represented a moment in Japanese music history when geisha were still paragons of fashion, beauty and artistic sophistication but were not yet solely conservators of living tradition symbolising a bygone era. During the early decades of the $20^{\text {th }}$ century, geisha, while still socially stigmatised by their association with the sex work of the floating world (which, partly due to Japanese officials' awareness of Western nations' moral judgement, was increasingly denigrated and marginalised), were nevertheless able to forge careers outside the hanamachi, alongside bel canto-trained singers and performers of new blues-and-jazz inflected styles of music. They did so on the crest of a wave of new technology that swept in from Europe and the United States: audio recording media and broadcast radio.

\section{A Century of Geisha Recording Artists}

Japanese popular music has always been a culturally hybrid entity. This makes knowledge of native genres and traditional performance practices essential to understanding its history. Such knowledge becomes even more important when approaching the history of recording technology in Japan. Central to this history were the geisha kashu. And given geisha's current image as guardians of Edo tradition, it is surprising to learn how extensively recording artists who emerged from the hanamachi combined traditional and imported musical elements to produce music that was both thoroughly modern and uniquely Japanese.

Early Years of Audio in Japan. Geisha were present from the very dawn of Japan's recording industry at the turn of the $20^{\text {th }}$ century. Although no details of her life remain, Yoshiwara Shimeji began her long career as a media star in 1905, recording hundreds of short songs and remaining a popular musical figure for nearly 30 years)--a remarkable achievement given the rarity and expense of audio technology in her time (Okada, 1997). 
Radio broadcasts commenced in 1925, and the demand for records began to skyrocket, as the domestic production of phonographic discs in 1927 resulted in lower prices, and the import of electrical recording technology the following year brought higher sound quality (Kurata, 1979). In 1928, Yoshichō Fumikichi became Victor's first exclusively contracted geisha singer and embarked on an illustrious 50-year career as Fujimoto Fumikichi. Her first big sellers, "Naniwa Kouta" (1929) and "Gion Kouta" (1930), were both theme songs for popular films--the former released only a month after Sato Chiyako's 1929 film theme, "Tokyo Kōshinkyoku" [Tokyo March], a benchmark in the development of Japan's popular song (Gōda, 2019b; Nagahara, 2017; Stevens, 2008). Although she never achieved the status of a mass media star, Fumikichi's artistic and financial success set the stage for a series of bona fide geisha superstars who debuted in the 1930s.

The Golden Age of the Geisha Singers. After Fujimoto Fumikichi forged a path out of the hanamachi, Kouta Katsutarō, her Yoshichō sister, released "Shima no Musume" [Island Girl] on Victor Japan in December 1932, a song that sold an unprecedented 500,000 copies. Katsutarō was also the first recording artist to join the ranks of kabuki actors and film stars featured on the covers of monthly magazines (Kurata, 1979, p. 357). Her live performances in large, public venues and live radio broadcasts were supplemented by appearances in make-up advertisements, making her a well-known figure in Japanese households of the day (Kurata, 1979, p. 358).

Ichimaru, an Asakusa geisha also signed to the Victor label, recorded "Chakkiri Bushi" [Tea-Cutting Melody] in 1931 as part of a PR campaign for the nascent tourist industry of Shizuoka Prefecture (a region famous for growing tea), indicating the early integration of media stars into lucrative networks of advertising. With her smash hits of 1933 and 1934, "Tenryū Kudareba [If You Go Down the Tenryū River]" and "Ryūkyō Kouta", Ichimaru achieved heights of fame (Shinobu Ichimaru, 1997). Victor (2007) cashed in on the success of these two geisha stars, spotlighting Ichimaru and Kouta Katsutaro in promotional plans that included film appearances, movie theme songs, advertisements and even a (fabricated) rivalry between the two singers, which Kodama describes as a moneymaking scheme on the part of the label (p. 94). When alto Akasaka Koume entered the limelight following her 1933 exclusive contract with Columbia and debut hit "Hontō ni Sō Nara" [If It Were Really So] (Osada, 1998), she, Katsutarō and Ichimaru were soon dubbed the geisha "three birds of a feather" [geisha kashu no sanbagarasu, lit. "nightingale-geisha-threecrows"] to indicate their elite status as top performers and recording artists (Hitobito wo miryō, 2017).

The appeal of geisha as media stars was so strong that a few aspirants circumvented the hanamachi while imitating the geisha look and sound. Otomaru, the daughter of a Tokyo cobbler who had lessons in tokiwazu narrative song and the short kouta genre--both closely associated with geisha was signed by Columbia in 1934 (Mori, 1995). Other labels like Japan Polydor and King Records also scouted young women from hanamachi in Japan's outlying regions, bringing them to the capitol for a chance at stardom in music and film. For example, according to the Japanese Film Database and Japanese Cinema Database, Hokkaido-born Michiyakko appeared in at least sixteen films between 1936 and 1952, many of which have been lost (Michiyakko, 2019; Michiyakko, 2020).

In addition to the dozen or so geisha singing stars who can be confirmed to have left their mark in Japanese popular music, dozens more remain shrouded in the mists of time. Voices etched into the grooves and names on the circular labels of $78 \mathrm{~s}$ or listed in archives indicate that there are many geisha kashu whose biographical details have been lost. Thankfully, some geisha-trained singers have recently been included on retrospective releases by Victor Japan and Columbia Japan (Fukkoku shinpen, 2005; Uguisu geisha, 2018). These 
recordings are valuable for researchers and fans alike; they also highlight the lack of more scholarly historical materials available about these influential singers.

From Media Stars to Lineage Masters. During the late 1930s and early 1940s, as social restrictions increased and the economy constricted, the geisha kashu remained important figures in popular music, especially once Japan went to war with the United States, and jazz and other cultural artifacts with overt association with the enemy were officially forbidden. Geisha stars recorded wartime songs and performed for Japanese troops abroad (Kodama, 2007; Yano and Tsujita, 2015). Kouta Katsutarō even met her future husband while on a three-week tour of the Chinese front in 1938 (Kodama, 2007). The uguisu geisha singers' position as media stars remained strong; although barely remembered today, geisha kashu Michiyakko, Mamechiyō and Nihonbashi Kimie played key roles in the 1942 operetta film Utau Tanuki Goten [Palace of the Singing Racoon Dog], a lavish mythic fantasy that allowed viewers to escape into the magical world of cinema, even as the war escalated all around (Kimura, 1942).

After the war, Japan again embraced the West, and jazz was once again all the rage. Piqued by Kasagi Shizuko's 1947 smash hit "Tokyo Boogie Woogie", Ichimaru recorded the popular "Shamisen Boogie Woogie" in 1949, sparking a post-war kouta boom and renewing the old genre with an infusion of the latest fashionable musical style. Osada (1991) attributes this innovative combination to Ichimaru herself, who approached "Tokyo Boogie Woogie" composer Hattori Ryōichi and asked him to write her a song combining Western rhythm with a so-called nihonchō [Japanese tuning] melody. For "Shamisen Boogie Woogie" Hattori used a major yonanuki [lit. four-seven-removed; i.e., pentatonic mode with no fourth or seventh scale degree] nihoncho and a tempo slow enough to allow Ichimaru to dance in heavy kimono and traditional hairstyle while singing. According to Osada, her televised performances proved her vitality and delighted her fans.

In 1950, Ichimaru followed up on this mass media success by joining the select troupe of musicians (led by composer Koga Masao) who were the first ${ }^{4}$ to leave post-war Japan on an officially sanctioned three-month tour of Hawaii and the United States (Geinōjin, 1950; Kirishima, Ichimaru ra kaeru, 1950). The following year, Ichimaru made a cameo as "Japan's number one geisha" in Tokyo File 212, a Hollywood B-movie filmed entirely on location - a film which Kitamura (2009) describes as both "intriguing" and a unique example of American Orientalism (pp. 505-507). Both of these instances exemplify the post-war effort to recast Japan's image into that of an American ally ( Shibusawa, 2006).

Post-war changes in Japanese government and society also led to the demise of longfading karyūkai structures, as prostitution was legally prohibited in 1956. The number of new geisha trainees sharply declined as hanamachi life was drained of its former panache. Some elder geisha kashu, such as Kouta Katsutarō and Shinbashi Kiyozō, followed the geisha tradition of retiring from their profession (in this case, from the recording and film industry) upon marriage. Other venerable performers recast themselves as masters of traditional genres, such as Akasaka Koume, who founded a lineage of minyo folk singing (Osada, 1998). In November 1969, Fujimoto Fumikichi received the Japanese Medal of Honour for Artistic Merit in recognition of her achievements in the classical performing arts, and Columbia released a 50-disc collection of her recordings of short shamisen song genres for which she had long been famous (Takeuchi, 2004). By 1981, all three "birds of a feather" geisha kashu (Kouta Katsutarō, Ichimaru and Akasaka Koume) had received the Medal of Honour. The Imperial Palace followed suit, recognising all four artists with the Order of the Sacred Treasure between 1971 and 1975.

Ichimaru demonstrated perhaps the most impressive artistic flexibility during this period. In 1960, Nakamura Kansaburō, the $17^{\text {th }}$ generation master of a venerable kabuki lineage, appointed Ichimaru as the iemoto head of the Edo Kouta school (Shinobu Ichimaru, 
1997). Although she continued to appear occasionally in popular media until her passing in 1997, the rebranded Edo Kouta Ichimaru increasingly shifted her musical focus towards preserving the traditional performing arts by teaching and recording repertory rather than churning out new hit songs (F. Suzuki, personal communication, February 6, 2020). The popular success of her post-war hit "Shamisen Boogie Woogie" notwithstanding, Ichimaru, once again sensing the cultural trends, transformed her public persona and her professional trajectory to align with the image of geisha as "traditional" rather than "popular". Unfortunately, her legacy seems to be in question regardless, as 2019's Ichimaru Prize, awarded annually to the best performer at the Victor Kouta Festival, may have been the last ("Dai Gojūkyūkai", 2019).

\section{Geisha Kashu and Japan's Early Popular Composers}

It is a testament to the historical importance of the geisha recording stars that many of the composers these women worked with remain venerated figures. But the geisha kashu have not enjoyed a similarly sustained level of acclaim - perhaps in part due to their lingering association with Japan's disavowed yükaku sex industry (Foreman, 2008; cf. Seigle, 1993). However, the fact remains that without the effort, talent and inspiration of geisha, Japan's popular music would not exist in its current for-and the music of some of Japan's bestknown composers could not have been realised. In this section, I examine the role several geisha singers played in the lives of two of Japan's most beloved songwriters.

The geisha kashu phenomenon from its very inception rested on a dual repertoire. On the one hand, the geisha singing stars brought a plethora of Edo Period short songs from their hanamachi training; on the other hand, studios promoted geisha singing new songs written by some of the biggest composers and lyricists of their day. Fumikichi Fujimoto's first hit film themes, Naniwa Kouta and Gion Kouta were both composed by Sassa Kōka (with lyrics by Shigure Otaha and Nagata Mikihito, respectively). Reflecting the success of Shinbashi Kiyozō's original 1935 rendition, composer Omura Nōshō's "Meiji Ichidai Onna" has been recorded by various geisha (and other) singers over the decades (Gōda, 2019a; Ichimaru, 1972). Japan's early composers all wrote songs to be recorded and performed by a variety of artists, including geisha kashu, who were also under contract at their record labels. However, the creative legacies of two icons of Japanese popular music history in particular, Nakayama Shinpei and Koga Masao, are intimately linked to the singing stars from the hanamachi.

\section{Nakayama Shinpei and Shinminyō: Locating Geisha Kashu in New Folk Music}

The founding father of Japanese popular music, Nakayama Shinpei composed "Kachūsha no Uta" [Katyusha's Song] in 1914 for a stage adaptation of Tolstoy's Resurrection. Lead actress Matsui Sumako's poignant rendition of the song was recorded on phonograph, garnering widespread attention and kicking off the domestic music industry (Kurata, 1979). Following this early success, Nakayama went on to write hundreds of popular songs, including "Tokyo Kōshinkyoku" (1929), the film theme recorded by operatic soprano Satō Chiyako (for Mizoguchi Kenji's film Tokyo March) that is widely considered to be Japan's first "hit record".

Nakayama became especially well-known for his regional shinminyō songs. Shinminyo [lit. new-folk-song] as a genre emerged in the early 1920s and comprised songs meant to be recorded by popular singers of all styles - including geisha kashu, who were sometimes selected to represent a town or area in the vicinity of their birthplace. As the name implies, shinminyō were inspired by regional minyō folk songs, even directly incorporating melodic, lyrical and thematic elements of these traditional songs. Geisha communities and geisha recording stars played an active role in the history of this genre, beyond performance 
and recording, as illustrated by the story of one of Nakayama's most enduring songs, "Tokyo Ondo".

"Tokyo Ondo" (with lyrics by Nakayama's frequent collaborator Saijo Yaso) was recorded in 1933 by minyō star Mishima Issei and Kouta Katsutarō, on the heels of her breakout success, "Shima no Musume" (Kodama, 2007, p. 180). "Tokyo Ondo" became another smash hit, and versions of the song (and its accompanying dance ${ }^{3}$ ) remain a key element of summer obon festivals as well as the team anthem for the Tokyo Yakult Swallows professional baseball team. "Tokyo Ondo" was a slightly adapted version of "Marunouchi Ondo", a popular song recorded by Fujimoto Fumikichi that Nakayama had composed the previous year. A third geisha, Shinbashi Kiyozō, provided musical inspiration for both of these songs.

"Marunouchi Ondo"/Tokyo Ondo" incorporate the instrumental prelude and other musical elements of "Kagoshima Ohara Bushi," a regional minyō song that Nakayama first heard in Japan's far west in 1930. Nakayama and lyricist Saijo were traveling to collect musical material and inspiration for their songwriting, when they encountered the geisha who would become well-known as recording star Shinbashi Kiyozō (Gōda, 2019b; Nakayama, 1958). This meeting not only resulted in one of Japan's most enduring popular tunes, it was also the beginning of a life-long relationship. Soon after meeting Nakayama, Kiyozō permanently relocated to Tokyo and signed with the Polydor label. In 1937, after passing of his wife, Nakayama married Kiyozō (who returned to her given name, Tane). Their marriage lasted until his death in 1952. In the late 1950s, Kiyozō came out of retirement to return to the spotlight with a tour of the United States - during which she spent time with singer Eartha Kitt, who was at the height of her popularity (Nakayama, 1958).

The Nakayama Shinpei Memorial Museum, on the outskirts of his rural Nagano hometown, downplays even the minimal evidence that exists of the musical and personal significance that geisha singers had in the composer's life, instead cultivating a more familycentred image of Nakayama and emphasising his large repertory of children's songs. The sidelining of geisha performers and their crucial role in Nakayama's musical career is symptomatic of a long-standing tendency to "clean up" Japanese music (cf. de Ferranti, 2002). Nevertheless, I was surprised when the helpful and forthcoming docents at the lovely Nakayama Shinpei Memorial Museum spoke to me in hushed tones about "Tane"-avoiding Kiyozō's geisha name and recording-star fame. When I breathlessly remarked that the vinyl disc of "Tokyo Ondo" in the museum display was a rare version recorded by Ichimaru, my enthusiasm was received as quirky rather than contagious. My experience only underlined the pervasive if unarticulated forces at play in the contemporary obscurity of the geisha recording stars.

\section{Koga Masao and Ryūkōka: Hanamachi Inspirations}

This tendency towards hushed tones, if not outright silence, concerning the geisha kashu and their biographies (musical and otherwise) can also be seen in discussions of the work of Koga Masao. From early in his long career, Koga, one of Japan's most iconic ryūkōka [lit. popularsong] composers, worked regularly with geisha and geisha-style recording artists-from Akasaka Koume and Otomaru in the 1930s to Kagurazaka Hanko and Kubo Yukie in the 1950s (Kurata, 1979; Mori, 1994; Mori, 1995; Nagahara, 2017; Osada, 1998). Today Koga is celebrated for the "Koga melody" style, which took hold in the pre-war period and, after the war, became an element in the codification of enka (Yano, 2002, pp. 36-37). He is also known for songs recorded by the so-called queen of enka, Misora who herself recorded and released several collections of hauta ${ }^{5}$ in her own signature vocal style Hibari (Yano, 2002, p. 39). 
Less well-remembered are Koga's lifelong associations with geisha; he was known to attend hanamachi parties where geisha performed and even act as a scout recruiting geisha singers (Gōda, 2019a). In 1933, just two years after his first hit song, he wrote Akasaka Koume's popular debut, "Hontō ni Sō Nara" [If It Were Really So], using a guitar to compose what became the shamisen part on the recording; the song itself was inspired by a phrase he heard repeated by geisha of the time (Osada, 1998). Later in the decade, Koga churned out a string of hits for Michiyakko, eventually writing the music for Kimura's 1942 film Utau Tanuki Goten.

In 1952, after meeting then-geisha Kagurazaka Hanko at a tea house performance, Koga helped launch her recording career with a new song, "Konna Watashi Janakatta Ni" [I Wasn't Like This] (Mori, 1995). This song has an upbeat, major yonanuki tune used poignantly in Naruse Mikio's 1954 film Late Chrysanthemums, a sympathetic portrayal of the hardscrabble denizens of Japan's fading hanamachi environs in the post-war period. While Koga is known as a seminal popular composer, it is not widely acknowledged that he worked and played with geisha singers throughout his career and his interactions with these recording artists were an important to his musical aesthetic. These lacunae occlude the fact that geisha were influential in the development of a range of early Japanese popular music styles, not just those now associated with "traditional" Japan.

\section{(Feminist) Listening and Audio Media: Re-examining the Karyūkai, Revalorising the Nightingale Geisha Singers}

Contemporary geisha rightly prize their status as living practitioners of Japan's unique cultural traditions; in order to achieve the social respectability needed to bolster that status, the public image of geisha in the $21^{\text {st }}$ century is (understandably) decoupled from the lingering stigma of the karyükai's sexualised labor in the $19^{\text {th }}$ and early $20^{\text {th }}$ centuries (Foreman, 2008). Yet the fact remains that these women's core artistic practices are deeply entwined with traditional iroke [lit. color-mood; i.e., sexy or seductive] eroticism (Dalby, 1979; Wright, 2016). Without a doubt, as detailed by Foreman (2008) and others, geisha are masters of musical lineages that allow women independence and strength in the context of an otherwise male-dominated field. Still, the conundrum of geisha creativity cannot be avoided, as aestheticised performances of romantic love and eroticism developed during centuries of state-sanctioned sexual commerce are intertwined with those traditions.

In encountering the captivating subtleties of these women's recorded voices, it is easy to gloss over the fact that much of their musical repertory is steeped in symbolism that idealises floating-world gender relations which seem flatly sexist by modern standards. Neglecting the complexities and contradictions of this historical context serves to obscure the stark history of Japanese sexual exploitation of women (including geisha), both domestically and abroad (Iwasaki, 2002; Masuda, 1957; Matsugu, 2006; Norma, 2016; Stanley, 2012; Stanley, 2013). How these social conditions influenced musical sound is far from straightforward, but the unique vocal qualities found in a popular song by the last geisha kashu (Gōda, 2019a) suggests just how important such considerations can be. Close listening to Kagurazaka Ukiko's "Pink Mood Ondo" illustrates how audio media can serve as a valuable sonic record of ephemeral aesthetic worlds.

Kagurazaka Ukiko was born in Tokyo in 1938. Inspired by the popularity of Kagurazaka Hanko (just six years her senior), Ukiko ${ }^{6}$ quit high school to become a geisha. This stint in the post-war karyükai was brief; encouraged by hanamachi encounters with "father of the song-writing world" Koga Masao, she signed a contract with Victor and made her recording debut in 1954 (Gōda, 2019a). She developed a popular image and performance sensibility that updated the traditional iroke aesthetic of geisha artists into an identifiably 
modern style of playful sexiness evoked by the English loanword 'pink' in the short-lived pinku kayō [lit. pink-song] genre (Gōda, 2019a). The Japanese connotations of this originally innocent word can be summed up in the term pinku chirashi [lit. pink-leaflet], which denotes small, cheaply-printed flyers for pornography and other sexual services that litter urban spaces with explicit images of women's bodies.

Just how much the classic geisha pop star sound had changed by the early 1960s is clearly audible in "Pink Mood Ondo," Ukiko's last hit before retiring to marry in 1963. Over a jaunty, light-hearted big-band accompaniment, Ukiko sings the common story of a young woman looking for romance on a spring evening. Her vocal production holds to a largely traditional timbre, placement and emphasis of the break. In the first verse, her light yuri vibrato (showing the influence of enka) and kobushi ornamentation at key points of the melodic line give no hint of what is to come - namely: sighs, airy groans and vocal fry that elicit a clear aural image of feminine desire. This vocal performance of sexuality becomes remarkably explicit in the second verse. When the lyrics describe a "kissu" (using the English loanword) that has left the singer sleepless and "writhing", the melody threatens to stall as its musicality briefly succumbs to Ukiko's overheated expressions of arousal. After a pause punctuated by a single guitar-string glide, the song is quickly back on track, showing the precise control and arch artifice of the singer.

"Pink Mood Ondo," while still broadly within the thematic and stylistic lineage of the geisha kashu, performs a modernised (albeit cheesy) sexiness that is doubtless clearly legible as such to contemporary listeners. As Gōda observes, Ukiko's "pheromone-infused" vocality flirted with obscenity restrictions without actually being banned from broadcast (2019a). While her vocal technique departs from that of her predecessors, her affront to social acceptability echoes the censorship issues that embroiled Katsutarō's explosive hit, "Shima no Musume" three decades earlier. In short, the age of the uguisu geisha kashu was bookended and hemmed in - by restrictions on the public expression of female sexuality.

\section{Fast Forward, Rewind: Listening to Women's Voices in Historical Perspective}

Of necessity, the cultural role and artistic significance of geisha today continues to shift. In the $21^{\text {st }}$ century, hanamachi activities remain economically vulnerable although local associations and tourist organisations acknowledge their continuing value and importanceboth in well-established hanamachi like Kyoto's and in far-flung towns like Fukushima Prefecture's Aizu-Wakamatsu ("Interview with a Geigi," 2020). Responding to the economic crisis brought about by the Covid-19 pandemic, the municipal government of Kanazawa has budgeted money in 2020 explicitly for the training of geisha, stating, "We hope [the financial aid] will help them cultivate their art in this difficult time" ("Performing Arts Thrown Lifelines," 2020). Furthermore, their continued openness and creative approach to technology is illustrated by Nara maiko [geisha-in-training] who have attempted to expand the reach of their four-person hanamachi by kicking off a YouTube channel in June 2020 (Okada, 2020).

Unfortunately, this well-deserved support seems to stop short of acknowledging these artists' historical links with technology — namely, the cutting-edge work of the geisha kashu recording stars, who remain largely unmentioned in both scholarly discussions and popular conceptions of Japanese music. This in turn creates gaps in what were actually cultural and sonic continuities between the Edo and Meiji eras, which then segued into Japan's burgeoning mass media industry at the dawn of the long Showa Period.

In conclusion, listening extensively to the vast body of recordings bequeathed by the geisha kashu and supplementing that listening practice with unflinching examination of the conditions under which these musicians emerged - reveals as-yet unexplored facets of Japanese media and popular culture. In their time, the geisha singing stars were beloved performing artists. Not only did Japanese audiences admire them, some of the country's most 
important composers sought them out as collaborators and intimates. Accordingly, they were instrumental in setting the trajectory of Japanese music, both popular and traditional.

They should languish neglected no longer. Acknowledging the geisha recording stars' contributions to a uniquely Japanese modernity will enrich the field of global media studies in a world that is increasingly digitally connected. Furthermore, scholars must ensure equal attention to female musicians, as we strive to create a world in which everyone's voice can be heard. This means dealing with all aspects of women's lives, including the realities and representations of sexuality and sexual exploitation. It is fundamentally a feminist act to listen carefully to women's voices-including both the full complexities of what they express and that which they are not allowed to utter freely.

\section{Acknowledgements}

I am grateful to Dr. Ogawa Masafumi for his support during my research fellowship in Japan, particularly through the unprecedented difficulties presented by the Covid-19 pandemic. I also wish to thank my dissertation advisor, Dr. Henry Spiller, for his ongoing encouragement. Finally, I am forever indebted to Mrs. Suzuki Fumi, Yoshi Karasawa and Barry Till for their time and generosity in sharing their invaluable knowledge.

\section{Endnotes}

\footnotetext{
${ }^{1}$ The museum director's informative blog (in Japanese) shows the breadth of their collection: https://www.kanazawa-museum.jp/chikuonki/kancho/index.html

${ }^{2}$ Shinbashi Kiyozō, for example, underwent half a dozen name changes during the fifteen years she spent working at geisha houses in Kyūshū, Taiwan (then a colony of Japan) and Tokyo.

${ }^{3}$ Ondo is a genre that typically includes a festive group dance (Hughes, 2008, p. 10). In the case of

"Marunouchi Ondo," and particularly "Tokyo Ondo," the public celebrations surrounding these songs were massive.

${ }^{4}$ Ichimaru's old rival Katsutarō arrived with a smaller group just days later (Hamamoto, 1950).

${ }^{5}$ Her earliest collection of hauta, Hibari Hauta Sōshi, from 1958, along with her 1952 cameo in Tsukigata

Hanpeita as the maiko Hinagiku, performing "Harusame Ni [In Spring Rain]", indicates that Misora's engagement with the traditional geisha short-song repertoire had a significant impact on her vocal transformation from post-war jazz wunderkind to diva of Japanese authenticity.

${ }^{6}$ The first character in Ukiko's stage name is the same as the first in ukiyo, the "floating" of the floating world evocative of both unconstrained freedom and lonesome ephemerality.
}

\section{References}

"Dai gojūkyūkai bikutā meiryū kouta matsuri, saigo no Ichimaru-shō. [59"th annual Victor notable kouta festival, final Ichimaru Prize]”. (2019, July 30). http://japojp.hateblo.jp/entry/2019/07/30/194545

Dalby, L. (1979). Little songs of the geisha: Traditional Japanese ko-uta. Tuttle Publishing.

Dalby, L. (1995). Courtesan and geisha: The real women of the pleasure quarter. In E. de Sabato Swinton (Ed.), The women of the pleasure quarter: Japanese paintings and prints of the floating world (pp. 47-65). Hudson Hills Press.

de Ferranti, H. (2002). "Japanese music" can be popular. Popular music, 21 (2), 195-208.

Downer, L. (2014). The city geisha and their role in modern Japan: Anomaly or artistes? In M. Feldman and B. Gordon (Eds.), The courtesan's arts: Cross-cultural perspectives (pp. 223-242). Oxford University Press.

Shinobu Ichimaru: Uta no hanamichi. [Ichimaru, in memoriam: Hanamichi of song] [Cassette]. (1997) [Liner notes]. Tokyo: Victor JVF.

Foreman, K. (2008). The gei of geisha: Music, identity, meaning. Ashgate Publishing.

Fukkoku shinpen kouta besuto 120 [Best 120 kouta rereleases and new versions][CD].(2005).[Liner Notes]. Victor Japan Traditional Cultures Foundation.

Geinōjin zokuzoku tōbei. [Performing artists to tour America]. (1950, April 5). Asahi shinbun, Tokyo edition.

Gōda, M. (2019a). [Liner notes]. Nihon no ryūkōka sutātachi 5 Kagurazaka Ukiko: Ukiko Kagurazaka greatest hits. [CD]. Victor Entertainment. 
Gōda, M. (2019b). [Liner notes]. Nihon no ryūkōka sutātachi 10 Fujimoto Fumikichi: Fumikichi Fujimoto greatest hits [CD]. Victor Entertainment.

Groemer, G. (2008). Popular music before the Meiji Period. In A. McQueen Tokita and D. W. Hughes (Eds.), The Ashgate companion to Japanese music (pp. 261-279). Ashgate Publishing.

Hamamoto, E. T. (1950, April 7). Three popular Japan musical stars arrive. The Hawaii Herald.

Hitobito wo miryō shita geisha kashu [The geisha singers that captivated audiences].(2017, August 25). Takeda Tetsuya no Shōwa wa kagayaiteita 192 [movie broadcast]. https://www.tvtokyo.co.jp/broad_bstvtokyo/program/detail/201708/23312_201708252100.html

Hughes, D. (2008). Traditional folk song in Japan: Sources, sentiment and society. Global Oriental.

Ichimaru. (1972/2007). Meiji ichidai onna [Recorded by company][CD]. Victor Entertainment.

Interview with a geigi: Higashiyama Onsen, Aizuwakamatsu. (2020, March 7). City-cost: Sharing experiences of life in Japan. https://www.city-cost.com/blogs/CityCost/zVqo4\%20living_aizuwakamatsu_shi_fukushima

Jude, G. (2018). Vocal processing in transnational music performances, from phonograph to Vocaloid [Unpublished doctoral dissertation, University of California Davis].

Kheshti, R. (2015). Modernity's ear: Listening to race and gender in world music [Kindle version]. New York University Press.

Utau tanuki goten [Palace of the singing raccoon dog].(2019, December 19). Nihon Eiga Database. http://www.jmdb.ne.jp/1942/br001080.htm

Kirishima, Ichimaru ra kaeru [Kirishima, Ichimaru and company return home].(1950, July 11). Asahi Shinbun, Tokyo edition.

Kitamura, H. (2009). Hollywood's new' Orientalism: The case of Tokyo file 212 (1951). Historical Journal of Film, Radio and Television, 29 (4), 505-522.

Kodama, Y. (2007). Geisha kara, meikashu e: Kouta Katsutarō no shōgai. [From geisha to famous singer: Biography of Kouta Katsutarō]. Self-published.

Kurata, Y. (1979). Nihon rekōdo bunkashi. [Cultural history of records in Japan]. Iwanami Gendai Bunko. Masuda, S. (1957/2003). Autobiography of a geisha. Translated by G.G. Rowley. Columbia University Press.

Matsugu, M. (2006). In the service of the nation: Geisha and Kawabata Yasunari's Snow Country. In M. Feldman and B. Gordon (Eds.), The courtesan's arts: Cross-cultural perspectives (pp. 243-252). Oxford University Press.

Michiyakko. (2019). Nihon eiga deitabeisu [Japan movie database] http://www.jmdb.ne.jp/person/p0331170.htm

Michiyakko. (2020). Japanese cinema database. Government of Japan, Agency for Cultural Affairs. https://www.japanese-cinema-db.jp/KeywordSearches/result\#staff_tbl

Misora, H. (1958). Hibari hauta sōshi [LP]. Columbia.

Mori K. (1994). [Liner notes]. Konna watashi janakatta ni [I wasn't like this][CD]. Nippon Columbia.

Mori K. (1995). [Liner notes]. Sentō kawaiya [Adorable boatman][CD]. Nippon Columbia.

Nagahara, H. (2017). Tokyo boogie-woogie: Japan's pop era and its discontentsI[Kindle version]. Harvard University Press.

Nakayama, Y. (1958/1999). Tajōbosatsu: Kiyozō jiden. [Boddhisatva of feeling: The autobiography of Kiyozō]. Ōzorasha.

Naruse M. (1954). Late chrysanthemums [Bangiku.] Film. Tōhō.

Norma, C. (2016). The Japanese comfort women and sexual slavery during the China and Pacific wars. Bloomsbury Academic.

Okada, M. (2010). Before making heritage: Internationalisation of geisha in the Meiji period. In C. Brumann and R. Cox (Eds.), Making Japanese heritage (pp. 31-43). Routledge.

Okada N. (1997). Yoshiwara shimeji to ryūkō uta rekōdo. [Yoshiwara Shimeji and early popular recordings.] Zoku shūshū kidan rekōdo korekutāzu, 76 (May), 106-111.

Okada, T. (2020, June 11). Proteges of last geisha in Nara district let loose as YouTubers. The Asahi Shinbun. http://www.asahi.com/ajw/articles/13445755.

Osada G. (1991). [Liner notes]. Iki, Ichimaru: Uta hitosuji rokujūnen [Elegant Ichimaru: 60 years of song] [Cassette and video box set]. Victor Entertainment.

Osada G. (1998). [Liner notes]. Hontō ni sō nara [If it were really so] [CD]. Nippon Columbia.

Performing arts thrown lifelines in Japan as virus puts damper on entertainment. (2020, June 28). The Japan Times. https://www.japantimes.co.jp/news/2020/06/28/national/local-japan-governments-subsidizecoronavirus-art-culture/

Seigle, C. S. (1993). Yoshiwara: The glittering world of the Japanese courtesan. University of Hawaii Press. Shibusawa, N. (2006). America's geisha ally: Reimagining the Japanese enemy. Harvard University Press.

Stanley, A. (2012). Selling women: Prostitution, markets, and the household in early modern Japan. University of California Press. 
Stanley, A. (2013). Enlightenment geisha: The sex trade, education and feminine ideals in early Meiji Japan. Journal of Asian studies, 72(3), 539-562.

Stevens, C. (2008). Japanese popular music: Culture, authenticity and power. Routledge Press.

Takeuchi M. (2004). [Liner notes]. Fuijimoto Fumikichi zenkyokushū ichi [Complete works of Fujimoto Fumikichi, disc one] [CD]. Columbia Music Entertainment.

Till, B., Warkentyne, M. \& Patt, J. (2001). From geisha to diva: The kimonos of Ichimaru. Art Gallery of Greater Victoria.

Uguisu geisha kashu to ryūkō kouta: SP-ban rekōdo no jidai. [The uguisu geisha kashu and popular kouta: The age of SP records][CD box set]. (2018). [Liner notes]. Columbia Japan.

Wright, Y. E. (2016). The arts of the geisha: Unravelling the artistic traditions and the aesthetics of iroke through an analysis of their dance and music [Unpublished doctoral dissertation]. University of Pittsburgh.

Yano, C. (2002). Tears of longing: Nostalgia and the nation in Japanese popular song. Harvard University Press.

Yano, T. and Tsujita, M. (2015). [Liner notes]. Minna wa ninare: Gunkoku ondo no sekai. [Everyone make a circle: The world of wartime songs][CD]. Gramoclub.

\section{Biography}

Gretchen Jude is a postdoctoral research fellow sponsored by the Japan Society for the Promotion of Science (Gakushin), in the Department of Music Education at Yokohama National University. Jude holds an MFA in Electronic Music and Recording Media from Mills College (California) and PhD in Performance Studies from the University of California Davis, as well as performance certification from the Sawai Koto Institute in Tokyo. Jude is currently working on a monograph about Ichimaru and her fellow geisha recording stars. 